\title{
Biodiversity Assessment AND Quality of a Vital State of Trees, Shrubs and Herbaceous Vegetation in Vicinity of Sport Objects of the Universiade (Kazan CITY, Russia)
}

\author{
Palagushkina O.V. \\ Zaripova N.R. \\ Mingazova N.M. \\ Gataullina G.R. \\ Ihsanova D.N.
}

Kazan Federal University, Institute of Management, Economics and Finance, Kazan, 420008, Russia

Email: opalagushkina@mail.ru

\section{Doi:10.5901/mjss.2015.v6n1s3p460}

\section{Abstract}

The article contains the information about the results of research of biological diversity and assessment of the quality of a vital state of trees, shrubs and herbaceous vegetation in vicinity of sport objects of the Universiade (Kazan city, Republic of Tatarstan). The vegetation of the city has been transformed in the construction of the Universiade objects. To improve the situation carried out extensive work on gardening. Provides the information about species compositions of trees, shrubs and herbs of sports facilities, about the most common species in planting of greenery. Identified the age and classes of vital state of trees. Among of herbaceous vegetation are marked prevailing families, ecological and coenotic groups and life forms, as well as rare and endangered species. The significance of compensatory measures identified to improve the environmental situation in the construction of sports facilities on the example of their greening.

Keywords: vegetation, biodiversity, vital state estimation, greening, sports objects, compensatory measures, Kazan city, Universiade

\section{Introduction}

Conservation of biodiversity is one of the key problems of sustainable development. The most important component of biodiversity is as a set of flora species of plants growing in a certain territory. In urban conditions, the biodiversity of plants focused on the territory of green spaces - parks, gardens, embankments, boulevards and squares, green protected zones. Urban Green areas play an important role in creating of suitable environment for people performing functions related to the release of oxygen and phytoncids, ionization of the air, deposition of dust, forming peculiar microclimate.

Major sporting events carry in themselves a huge transformational potential for places where they are go. Universiade is the second largest sporting event after the Olympic Games around the world. For the hosting of the Universiade in Kazan (Tatarstan, Russia) were involved 49 sports objects, and 36 of them were built specifically for this event. Active construction and transformation of the urban environment has had a significant negative impact on all main components of the urban ecosystem, including on the species richness of plants and the degree of greening of the city. The degree of greening the city was in 2002-2004 about 24\%, in 2007-2008 about 17\% according to the inventory of green spaces of common use (excluding greening residential areas). The degree of greening has decreased significantly (about $2 \%$ ) in 2009-2011 as a result of the construction of sports facilities for Universiade. At the same time to optimize the environmental situation in the cities is necessary that the degree of greening the urban area was $40-50 \%[4,9,10]$.

Greening is the cheapest and most effective way to improve the environmental situation in the city. For the elimination of negative consequences of constructions the municipal authorities have been implemented special programs "100 squares" (2011) and "Green record" (from 2012) for a sharp increasing of the degree of urban greening, beautification of green areas and creating a favorable environment in the future.

The main goal of the carried-out work was studying of biological diversity and vital conditions of trees and shrubs and grass vegetation near sports objects of the Universiade in Kazan in 2013. It were held the definition the taxonomic 
diversity of plants, including the identification of rare and endangered species, the definition of eco-cenotic groups, life forms of herbaceous plants and vital conditions of trees and shrubs in the area of green space of sports objects of the Universiade.

\section{Materials and Methods}

Studies of green spaces of sports objects of the Universiade carried out in June-July of 2013 in the six administrative districts of Kazan - Aviastroitelny, Vakhitovsky, Kirovsky, Novo-Savinovsky, Privolzhsky and the Sovietsky in 14 sports objects. There are seven stadiums - "Kazan - Arena", "Olympus", "Ruby", "Labor reserves", "Rocket", "Tennis Academy", "Central Stadium"; three sports palaces: "Sports Palace", "Palace of single combats Ak Bars", "Palace of water sports"; and two sports complexes - "Olympian", "Bustan", and territories of the Universiade Village and the Center for rowing sports.

Methods of a gerbarization of plants, making of the trial areas, route supervision used. For definition of species of plants were used a special key books $[1,5,6,13]$. Special eco-coenotic groups were determined on a scale of Cyganov, life forms - on classification Raunkier [2,7,11,12]. For assessing of vital state of green spaces determined the class of resilience of trees and shrubs, and evaluation of the quality of lawns and flowerbeds [8].

\section{Results}

The Tatarstan Republic is located in the European part of the Russian Federation, at the confluence of the Volga and Kama rivers. The length of its territory from west to east is $460 \mathrm{~km}$, from north to south - $290 \mathrm{~km}$. Tatarstan Republic is one of highly urbanized regions: the proportion of urban population is $73.6 \%$ (there are 20 towns and 21 townships). Kazan is the capital of the Republic of Tatarstan, and a place of the hosting of the XXVII World Summer Games of the Universiade.

Choice of Kazan as a place of major sporting event is associated, in particular, with geographical features of the city. Kazan climate is moderately continental with warm summer and moderately cold winter. The duration of sunshine per year on average 1916 hours. The sunniest is the period from April to August. The cloudiest month is November. Rainfall area belongs to the zone of moderate humidity. During the negative average daily temperatures precipitation falls as snow, forming a blanket of snow. The number of days with snow cover around 150. The height of the snow cover reaches its highest values in March [4].

According to the inventory of green spaces of Kazan in 2007-2009 the are 697 green objects: the streets (508), parks (16), gardens (5), squares (109), green areas (58), and Forest Park "Lebyazhye" in the status of protected area of local importance $[4,9,12]$. The largest number of squares, gardens, parks concentered in Vakhitovsky district, and the largest number of green areas located in Privolzhsky and Sovietsky districts of Kazan. Of the 71 species of trees and shrubs commonly used in planting of greenery Tilia cordata Mill., Betula pendula Roth, Acer negundo L. To these species in different districts of the city were added Populus of section Tacamahaca ore balsamic poplars and Pinus sylvestris $L$. According to research of 2007-2009, the most depleted in the plan of green spaces was Aviastroitelny district. Low amount of green spaces in the vicinity explained by dense buildings and a large number of industrial zones. The greatest number of gardens and parks noted in Vakhitovsky district. This district is central and has a great recreational load and a historical value. Lot of old green spaces preserved due to building of low intensity and saving the architecture of the historic center $[4,9,12]$.

Due to of construction in recent years, including the preparation of the Universiade, the proportion of green spaces and greening percentage decreased, suffered about 30 green spaces. In addition, many green spaces streets have suffered as a result of the construction of transport routes and passages. To address the impact of municipal programs began to be carried out on gardening [9].

Since 2012 because of the implementation of programs greening of the city planted trees, number has increased by 47800 . In 2013 were planted more than 50000 trees [9].

The largest greening took place of the newly built sports objects - Football stadium "Kazan Arena", "Palace of single combats", "Palace of water sports" (Novo-Savinovsky district), Center for rowing sports (Privolzhsky district). In general, 17 species of tree and 9 species of shrub vegetation (total 3567 things) grows at the territories of investigated sports objects (tables 1, 2).

The most often used in greenery from trees Picea abies (L.) Karst. (about $44 \%$ from all recorded trees), Tilia cordata (12\%) and Sorbus aucuparia L. (9\%). The predominant age of the trees growing in the sports objects is up to 15 years, the proportion of this age group accounts for almost $92 \%$ of the total examined trees. Vital state of the trees 
assessed mainly by first and second classes of quality - highly decorative healthy and slightly weakened trees.

Greening by means of shrub vegetation applied only on a half of the studied sports facilities. From nine are the most common species identified - Berberis vulgaris L., Syringa vulgaris L., Rubus idaeus L. (Table 2).

In the composition of species of herbaceous vegetation from the 14 sportive objects of the Universiade revealed 180 species from 56 families. The greatest number of species have families Astraceace - 25 and Fabaceae - 18, up from 14 and 10\% of the total number of species. Families Poaceae - 14 and Rosaceae - 11 are 8 and $6 \%$ of the total number of species, respectively. The rest of the families contribute to the total species composition from 4 to $0,6 \%$ Polygonaceae - 8; Cyperaceae - and Lamiaceae - every by 7 species; Brassicaceae - 6 species. The following three families contain from five species for every: Apiaceae, Ranunculaceae and Salicaceae; Potamogetonaceae, Pinaceae and Saryophyllaceae - four species; Lemnaceae, Typhaceae, Chenopodiaceae, Boraginaceae and Solanaceae - 3 species; Alismataceae, Plantaginaceae, Primulaceae, Onagraceae, Rubiaceae, Aceraceae, Betulaceae, Equisetaceae and Oleaceae - 2 species.

Table 1. The list of species of trees and occurrence in the territory of sporting venues of Universiade

\begin{tabular}{|c|c|c|c|c|c|c|c|c|c|c|c|c|c|c|}
\hline \multirow[b]{2}{*}{ Species } & \multicolumn{7}{|c|}{ Stadiums } & \multicolumn{3}{|c|}{ Sports palaces } & \multicolumn{4}{|c|}{ Others } \\
\hline & $\begin{array}{l}\overline{\bar{a}} \\
\stackrel{\bar{\partial}}{\underline{\underline{O}}}\end{array}$ & 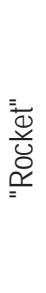 & 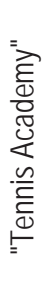 & 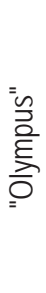 & 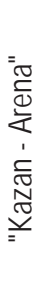 & 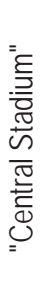 & 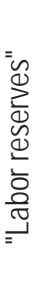 & 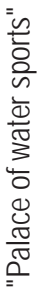 & 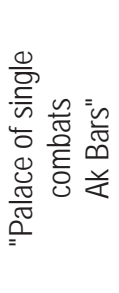 & 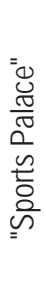 & 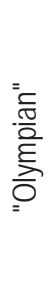 & 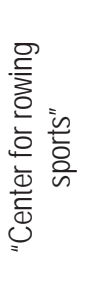 & 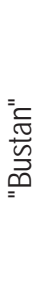 & 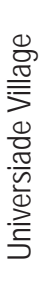 \\
\hline Acer negundo L. & + & + & & & + & + & + & & + & & + & & + & + \\
\hline A. tatarcum L. & & & & & & & & & & & + & & & \\
\hline Betula pendula Roth & + & + & + & & & + & + & & & & + & & + & + \\
\hline Fraxinus excelsior L. & + & + & & & & & & & & & + & & & \\
\hline Larix decidua Mill. & & & & + & & + & & & & & & & & + \\
\hline Picea abies (L.) Karst. & + & + & + & & + & & + & + & + & + & & + & & \\
\hline Picea ×fennica (Regel) Kom. & & & & & & & & & & & & & + & \\
\hline Pinus sylvestris L. & + & + & & & & + & + & & & & + & + & & + \\
\hline Populus alba L. & + & & & & & & & & & & & & + & \\
\hline P. italica (Du Roi) Moench & & & & & & & & & & & & & + & + \\
\hline P. nigra L. & & + & & & & & & & + & & + & + & & + \\
\hline Salix alba L. & & & & & & & & + & & & & & & \\
\hline Sorbus aucuparia L. & + & + & & + & & + & & & & & + & + & + & + \\
\hline Tilia cordata Mill. & + & & + & + & & + & + & & + & + & + & & + & + \\
\hline Thuja occidentalis L. [ & & & & & & & & & & & & & + & + \\
\hline Ulmus glabra Huds. & + & & & & & & & & & & & + & & \\
\hline Quercus robur L., & & & & & & & & & & & & & & + \\
\hline
\end{tabular}

Most rare families (represented only by one species of plant) were Amarabthaceae, Asparagaceae, Berberidaceae, Butomaceae, Campanulaceae, Cannabaceae, Ceratophyllaceae, Convolvulaceae, Crassulaceae, Cucurbitaceae, Dipsacaceae, Euphorbiaceae, Haloragaceae, Juncaceae, Lentbulariaceae, Lythraceae, Papavaraceae, Salviniaceae, Scrophulariaceae, Sparganiaceae, Tiliaceae, Ulmaceae and Vitaceae.

In the territory of the investigated objects of the Universiade (floodplain of the river Kazanka) found two rare species of plant (listed in the Red Book of the Republic of Tatarstan) - Salvinia natans (L.) All and Urticularia vuigaris L. Earlier this territory mentioned 9 rare species, the construction has reduced the number of rare species. Decreasing biodiversity increases the amount of environmental damage caused during the construction of the Universiade objects [3]. 
Table 2. List of species of shrubs and occurrence in the territory of sporting venues of Universiade

\begin{tabular}{|c|c|c|c|c|c|}
\hline Species & 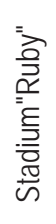 & 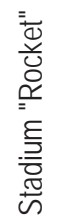 & 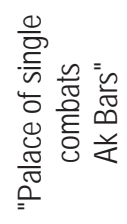 & 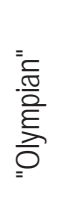 & 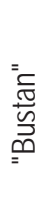 \\
\hline Berberis vulgaris $L$. & + & & & & \\
\hline Crataegus sanguinea Pall. & & + & & & \\
\hline Corylus avellana $\mathrm{L}$. & + & & & & \\
\hline Parthenocissus inserta (Kern.) K. Fritsch & & & + & & \\
\hline Rosa majalis Herrm. & & & + & + & \\
\hline Rubus fruticosus $\mathrm{L}$. & & & + & & \\
\hline Rubus idaeus L. & & & + & & \\
\hline Salix caprea L. & + & & + & & + \\
\hline Syringa vulgaris $\mathrm{L}$. & + & & & & + \\
\hline
\end{tabular}

From 180 species of plants, belonging to the eco-cenotic groups found for 86 species with a predominance of species of meadows and forest edges (from 25 to 100\% of the number of identified species). Were widely distributed species of wetlands (40 to 100\%), of which "nitrophilous" and "tall" are from 5 to 10\%. Nemoral species comprise from 5 to 20\%, boreal species - from 3 to $5 \%$ are least presented. Dominant life forms of herbaceous vegetation were cryptophytes perennial grasses (113 species), terophytes - annual grasses (38 species) and fanerophytes (26 species). The lowest number of species observed among hamephytes - only 3 species.

Areas occupied by lawns amounted around 26 hectares and quality of lawns was assessed mainly 2-3 categories (as satisfactory - unsatisfactory condition). Areas occupied by flowerbeds were small - about $1200 \mathrm{~m}^{2}$, with first or second categories of quality (good - satisfactory condition).

\section{Conclusions}

Because of researches in territory of 14 sportive objects of the Universiade found 17 species of trees. The most often used in greenery Picea abies, Tilia cordata and Sorbus aucuparia. The predominant age of the trees growing in the sports objects is up to 15 years, vital state of the trees assessed mainly like a highly decorative healthy and slightly weakened trees. Greening by means of shrub vegetation applied only on a half of the studied sports facilities. From nine species of shrub vegetation are the most common species Berberis vulgaris, Syringa vulgaris, Rubus idaeus. At research of herbaceous vegetation were identified 180 species of 56 families with a predominance of Asteraceae, Fabaceae and Poaceae.

Species of meadows and forest grow at all sites around the Universiade objects, widespread are species of wetlands, less common are nemoral species; the rarest are boreal species. Predominant life form of herbaceous vegetation were cryptophytes the rarest were hamephytes. Have also highlighted two rare, listed in the Red Book of species of the Republic of Tatarstan - Salvinia natans and Urticularia vuigaris. Earlier in the territory of the floodplain Kazanka noted 9 rare species, the construction in the floodplain has disrupted habitat of rare species.

Carrying out of countervailing greenery measures, including, the territory of sports facilities, helped to increase the degree of greening, renewal and rejuvenation of the tree and shrub vegetation. These activities helped to partially compensate for damage to the environment from the effects of the construction of the Universiade objects.

\section{References}

Bakin O.V., Rogova T.V., Sitnikov A.P. Vascular plants of Tatarstan // Kazan: Kazan university Press, 2000. - 496 p. (in Russian).

Bobrowski M.V., Khanina L.G, Quantitative estimation of vegetation diversity at the local level for forest inventory data // Forest Science. 2004. (№ 3), p. 28-34. (in Russian).

Derevenskaya O.Yu., Mingazova N.M., Mingaliev R.R., Pavlova L.R. Assessing Economic Losses of the Small River Ecosystems and Developing of Compensation Measures within the Framework of Sports Facilities Construction // Mediterranean Journal of Social Sciences. MCSER Publishing, Rome-Italy. 2014. - P. 345-348.

Ecology of Kazan city // Edited by Mingazova N.M. et al. - Kazan: publishing house "Fen", 2005. - 573 p. (in Russian). 
Illustrated key book of Plants of Central Russia // VS Novikov (et al.) In 3 volumes, M.: KMK, Institute of technical studies. Vol. 1, 2002526 p., V.2, 2003 - 665 p., V.3, 2004 - 520p. (in Russian).

Key book of the Plants of Tatarstan // Kazan: Kazan university Press, 1979. - 372 p. (in Russian).

Kokin K.A. Ecology of higher plants// M.: Moscow university Press, 1982. - 160 p. (in Russian).

Methods of assessing of the ecological state of public green spaces of St. Petersburg, approving the order dated 30 August $2007 \mathrm{~N} 90$ p, 13p. (in Russian).

Mingazova N.M., Nikitin A.V., Yupina G.A., Derevenskaya O.Yu. Strategy of Management of City Development with Using «Green» Technologies (Kazan City, Russia) // Mediterranean Journal of Social Sciences. MCSER Publishing, Rome-Italy. 2014. - P. 341343.

Mingazova N.M., Yupina G.A., DerevenskayaO.Yu., Illarionova M.N. Ecology. Environment. Water bodies and green areas. // Urbanrevitalization and redevelopment of Volga district territories in the city of Kazan (Center Waterfront Area of Volga River). International Urban design workshop. Background information. - Kazan, 2008. - P. 24- 25.

Rabotnov T. A. Phytocenology // M.: Moscow university Press, 1978. - 230 p. (in Russian).

Melnik A.N., Ermolaev K.A., Antonova N.V.Stages in Formalizing Energy Conservation and Efficiency Management in Industrial Enterprises// Mediterranean Journal of Social Sciences.- Vol.5, No12, (2014)-pp.173 - 176.

Serebryakov I.G. Ecological morphology of plants. Life forms of angiosperms and coniferous plants// M .: High school, 1962. (in Russian).

Melnik, A.N., Mustafina, O.N. (2014). The liberalization of electricity market in the system of measures for improving industrial enterprisers competitiveness: The case of Russia. Mediterranean Journal of Social Sciences, 5 (18 SPEC. ISSUE), pp. 293-298.

Kinossian, N. (2012). Post-Socialist Transition and Remaking the City: Political Construction of Heritage in Tatarstan. Europe - Asia Studies, 64 (5), pp. 879-901.

The Red Book of the Republic of Tatarstan (animals, plants, fungi)// Second edition, Kazan: Idel-Press, 2006. - 832 p. (in Russian).

Klychova G.S., Zakirova A.R., Mukhamedzyanov K.Z., Faskhutdinova M.S. Management reporting and its use for information ensuring of agriculture organization management // Mediterranean Journal of Social Sciences vol. 5 № 24, November 2014, pp. 104-110 